\title{
Effects of dietary fibre-rich juice colloids from apple pomace extraction juices on intestinal fermentation products and microbiota in rats
}

\author{
Sabine Sembries ${ }^{1 *}$, Gerhard Dongowski ${ }^{1}$, Gisela Jacobasch ${ }^{1}$, Katri Mehrländer ${ }^{2}$, Frank Will ${ }^{2}$ \\ and Helmut Dietrich ${ }^{2}$ \\ ${ }^{1}$ German Institute of Human Nutrition, Department of Food Chemistry and Preventive Nutrition, \\ D-14558 Bergholz-Rehbrücke, Germany \\ ${ }^{2}$ State Research Institute Geisenheim, Department of Wine Analysis and Beverage Research, PO Box 1154, \\ D-65366 Geisenheim, Germany
}

(Received 16 December 2002 - Revised 10 April 2003 - Accepted 28 April 2003)

\begin{abstract}
Effects of colloids isolated from apple pomace extraction juices (so-called B-juices) produced by enzymic liquefaction on food intake, body and faecal weights, short-chain fatty acid (SCFA) profile and selected intestinal microbiota were investigated in rats. Ten male Wistar rats per group were fed diets without any apple dietary fibre (DF) (control) or supplement with 5\% B-juice colloids or an alcohol-insoluble substance (AIS) from apples for 6 weeks. Rats fed with apple DF (5\% B-juice colloids or AIS) gained less weight than control rats $(P<0 \cdot 05)$. B-juice colloids did not affect food intake, whereas feeding AIS resulted in a $10 \%$ higher food consumption than in control rats. Both juice colloids and AIS increased the weight of caecal contents in rats and lowered luminal pH values $(P<0.05)$. In addition, SCFA concentrations and total yields were also raised $(P<0.05)$ in caecum of these rats indicating good fermentability of apple substrates by gut microflora. Distinctly higher concentrations of acetate and propionate were found in intestinal contents of juice colloid-fed rats $(P<0.05)$, whereas AIS also increased butyrate yield. Changes in microbiota due to apple DF in diets were restricted in the caecum to the Eubacterium rectale cluster (AIS; $P<0.05$ ) and in faeces to the Bacteroidaceae (juice colloids and AIS; $P<0.05$ ). The present study shows the physiological effects of apple DF isolated from pomace extraction juices produced by enzymic liquefaction on intestinal fermentation. Results may be helpful for the development of such innovative juice products that are rich in DF of fruit origin.
\end{abstract}

Apple-juice colloids: Pomace extraction: Short-chain fatty acids: Microbiota

Dietary fibre (DF) plays an important role as indigestible food components in human nutrition due to their beneficial effects for health. Mainly consisting of NSP, oligosaccharides and resistant starch, they have water-binding properties thus increasing volume and viscosity of intestinal contents. DF are responsible for faecal bulking, enhancing gut motility and lowering transit time. Being indigestible in the small intestine, they finally reach the colon, where they are utilized as fermentation substrates by the gut microflora. In the colon, a symbiosis through fermentation exists between the host and intestinal bacteria. Released as main microbial fermentation products, the short-chain fatty acids (SCFA) acetate, propionate and butyrate are rapidly absorbed by the colonic epithelium, which stimulates water and $\mathrm{Na}^{+}$absorption (Mortensen \& Clausen, 1996; Velázquez et al. 1997). Furthermore, especially butyrate is a preferred substrate for the colonocyte. It serves as an energy source and is known to contribute a trophic effect on colonic mucosa (Roediger, 1980;
Velázquez et al. 1996; Salminen et al. 1998). With the knowledge of these beneficial effects of DF, a great deal of effort has been made to positively modulate the composition of intestinal microflora and of SCFA via pre- and probiotics (Steer et al. 2000); for example, the bifidobacteria with inulin and oligofructose to maintain a normal and healthy gut microflora and also immune regulation in the colon (Gibson et al. 1995; Gibson \& Roberfroid, 1995; Gibson, 1999; Kruse et al. 1999).

In apples, the main DF constituents are NSP such as cellulose, hemicelluloses and pectin, which have been shown to be good fermentation substrates for intestinal bacteria in previous studies (Vince et al. 1990; Tietgemeyer et al. 1991; Guillon et al. 1995; Casterline et al. 1997; Lebet et al. 1998; Van Laere et al. 2000). Such cell-wall components DF character are partially released into juice during apple-juice production. By using liquefying enzymes, for example, pectinases and cellulases, physiologically valuable apple juices can be produced in a two-step mode 
(Will et al. 2000). The first step consists of a common pectolytic mash treatment yielding the premium juice (A-juice) after separation. Subsequently, the remaining pomace is enzymically extracted a second time with cellulases and/or pectinases. Besides higher juice yields, this resulting pomace extraction juice (B-juice) contains higher amounts of polyphenols and up to ten times more DF compared with the corresponding A-juice (Bauckhage et al. 2000; Sembries et al. 2000; Will et al. 2000). The latter is equivalent to commercially available cloudy juices. DF-rich colloids isolated from B-juices have been characterized previously (Mehrländer et al. 2002).

Applying this process efficiently enhances the extraction of valuable fruit ingredients from apples (for example, DF and polyphenols) from which very high concentrations otherwise remain unused in pomace. B-juices high in DF and polyphenols are promising as new fruit-juice products; they can therefore be considered a natural alternative for functional drinks. No external addition of DF components should be necessary due to the presence of a sufficient amount of DF released from fruits during enzymic treatment. Concerning the daily recommended DF intake, B-juices from apple pomace seem to be more 'healthy' than clarified apple juices containing practically no DF at all. Another advantage of applying this two-step mode is the fact that the underlying engineering process necessary to obtain these valuable fruit-juice products merely requires applying some already existing techniques of common juice technology.

Here, the present study tested the potential healthpromoting effects of isolated DF-rich B-juice colloids for their potential use as a food ingredient in B-juices.

To our knowledge there are no data available in the literature about the physiological effects of such apple juice colloids isolated from pomace extraction juices on intestinal fermentation. Therefore, the effects of corresponding B-juice colloids on fermentation products and degrading organisms were investigated. In the present study, DF-rich colloids from B-juices were isolated and examined in rats with regard to food intake, body and faecal weights, SCFA profile and some intestinal microbiota. Additionally, an alcohol-insoluble substance (AIS) was prepared from apples and tested. Having an almost intact cell-wall structure, the AIS served as a counterpart to soluble juice colloids released during the enzymic pomace treatment.

\section{Materials and methods}

\section{Juice colloids and alcohol-insoluble substance}

Juice colloids were isolated from apple pomace extraction juices $1 \mathrm{~B}$ and $4 \mathrm{~B}$, which were produced by enzymic liquefaction (Will et al. 2000). The extraction juice 1B was produced solely by water extraction of pomace without any additional enzymes, whereas juice 4B was obtained after a pectolytic and cellulolytic pomace treatment. For isolation of juice colloids, both pomace extraction juices were concentrated using preparative ultrafiltration first (Bucher/Abcor, Niederweningen ZH, Switzerland; cut-off $18000 \mathrm{Da}$ ). Subsequently, to one part of retentate five parts of $96 \%(\mathrm{v} / \mathrm{v})$ ethanol were added to precipitate colloids. Filtrated colloids were washed in ethanol and dried at $60^{\circ} \mathrm{C}$. The total DF content of isolated juice colloids 1B was $56.9 \%(54.3 \%$ soluble, $2.6 \%$ insoluble DF); DF content of juice colloids obtained from extraction juice 4B was $80.1 \%(78.3 \%$ soluble, $1.8 \%$ insoluble DF) as determined by the Association of Analytical Chemists method (Prosky et al. 1988). 'Soluble' DF-rich colloids mainly consisted of oligo- and polymeric arabinans, rhamnogalacturonans and arabinogalactans (Mehrländer et al. 2002). 1B colloids had the following monosaccharide composition (mol \%): rhamnose, 3; arabinose, 20; galactose, 8; glucose, 11; xylose, 1; galacturonic acid, 57. 4B colloids had the following monosaccharide composition (mol \%): rhamnose, 5; arabinose, 23; galactose, 6; glucose, 7; xylose, 1; galacturonic acid, 57. AIS was prepared from freshly harvested apples (variety 'Boskoop'; Werder Frucht, Glindow, Germany). In portions, $45 \mathrm{~kg}$ washed apples with skins and cores were crushed into small pieces in two parts of $96 \%(\mathrm{v} / \mathrm{v})$ ethanol using a blender and an Ultra-Turrax T25 (Jahnke \& Kunkel, IKA Labortechnik, Staufen, Germany) and boiled under reflux for $15 \mathrm{~min}$. The liquid phase was removed by suction; thereafter, the residue was washed with $65 \%$ (v/v) ethanol and extracted again. Then, it was sequentially dehydrated in 65,80 and $96 \%(\mathrm{v} / \mathrm{v})$ ethanol followed by acetone. The vacuum-dried AIS was milled to a particle size of $\leq 0.5 \mathrm{~mm}$. It contained $96.2 \%$ total DF $(22.9 \%$ soluble, $73.3 \%$ insoluble DF). The 'soluble' DF parts of AIS consisted of $20.7 \%$ total pectin $(4.3 \%$ water- and $6.5 \%$ EDTA-soluble) with a degree of esterification of $83 \%$.

\section{Animals and diets}

The experimental protocol was performed in accordance with the guidelines of the ethics committee of the Ministry of Agriculture, Nutrition and Forestry (State Brandenburg, Germany, permission no. L8-3560-0/3). Forty male Wistar rats (Shoe-Wistar; Tierzucht Schönwalde, Schönwalde, Germany) weighing 177 (SD 4) g were randomly divided into four groups of ten animals each and were kept in a temperature-controlled environment $\left(22 \pm 2^{\circ} \mathrm{C}\right)$ with a $12 \mathrm{~h}$ light-dark cycle. After adapting to the semi synthetic control diet (Table 1) for a period of 1 week, the three test groups were fed a diet supplemented with either DF-rich colloids isolated from extraction juice $1 \mathrm{~B}$ or $4 \mathrm{~B}$, or with AIS from apples (Table 1) for 6 weeks. The control group rats were maintained on the control diet. Rats had free access to water and to their respective diets. Food consumption and body weight were monitored weekly.

\section{Sampling procedures}

At the end of the adaptation period and on weeks 3 and 6 of the experimental period, fresh faecal samples were collected directly from the anus and were immediately processed for microbial counts. For analysis of SCFA, samples were frozen and stored at $-20^{\circ} \mathrm{C}$ until preparation for GC analysis. Fresh sample aliquots were taken for the determination of $\mathrm{pH}$ values and dry weights. Microbial counts in faeces were done at the end of the adaptation period as well as at the end of feeding the respective diets on 
Table 1. Composition $(\mathrm{g} / \mathrm{kg})$ and dietary fibre (DF) content $(\mathrm{g} / 100 \mathrm{~g}$ dry weight) of diets

\begin{tabular}{|c|c|c|c|c|}
\hline \multirow[b]{2}{*}{ Ingredients } & \multicolumn{4}{|c|}{ Diet } \\
\hline & Control & Colloids 1B & Colloids 4B & AIS \\
\hline Casein* & 200 & 200 & 200 & 200 \\
\hline Wheat starch $†$ & 630 & 580 & 580 & 580 \\
\hline $\begin{array}{l}\text { Sunflower-seed } \\
\text { oilł }\end{array}$ & 50 & 50 & 50 & 50 \\
\hline $\begin{array}{l}\text { Microcrystalline } \\
\text { cellulose§ }\end{array}$ & 50 & 50 & 50 & 50 \\
\hline Mineral mixture\| & 50 & 50 & 50 & 50 \\
\hline Vitamin mixture\| & 20 & 20 & 20 & 20 \\
\hline Colloids 1B & - & 50 & - & - \\
\hline Colloids 4B & - & - & 50 & - \\
\hline $\begin{array}{l}\text { AIS } \\
\text { DF content }\end{array}$ & - & - & - & 50 \\
\hline Total & $6 \cdot 2$ & $9 \cdot 8$ & 8.4 & $12 \cdot 7$ \\
\hline Soluble & 0.2 & 4.0 & $1 \cdot 7$ & $2 \cdot 4$ \\
\hline Insoluble & $6 \cdot \overline{0}$ & $5 \cdot 8$ & $6 \cdot 7$ & $10 \cdot 3$ \\
\hline
\end{tabular}

AIS, alcohol-insoluble substance.

${ }^{*}$ Hermann Kröner GmbH Co. KG, Ibbenbüren, Germany.

† Bayerische Milchindustrie eG, Landshut, Germany.

$\ddagger$ Plus Vertriebs GmbH, Mühlheim/Ruhr, Germany.

§J. Rettenmaier \& Söhne GmbH \& Co., Ellwangen-Holzmühle, Germany.

\| Altromin $\mathrm{GmbH}$, Lage, Germany. Mineral mixture contained $(\mathrm{mg} / \mathrm{kg})$ : Ca,

146 070.34; P, 97355.04; Mg, 8784.27; Na, 39229.41; K, 116 496.45; S, 10535.81; Cl, 63510.38; Fe, 2931.22; $\mathrm{Mn}, 1733.86 ; \mathrm{Zn}, 387.54 ; \mathrm{Cu}$ 85.21; I, 7.50; Mo, 3.31; F, 70.08; Se, 3.84; Co, 2.06; Al, 0.07. Vitamin mixture contained $(\mathrm{mg} / \mathrm{kg})$ : vitamin $A, 225$; vitamin $D_{3}, 0.625$; vitamin $E$ 7500 ; vitamin $\mathrm{K}_{3}, 500$; vitamin $\mathrm{B}_{1}, 1000$; vitamin $\mathrm{B}_{2}, 1000$; vitamin $\mathrm{B}_{6}, 750$; vitamin $\mathrm{B}_{12}$, 1500; nicotinic acid, 2500; pantothenate, 2500; folic acid, 500 biotin, 10; choline chloride, 50000; $p$-aminobenzoic acid, 5000; inositol, 5000; vitamin C, 1000; methionine, 173250.

q Determined by the Association of Analytical Chemists method.

week 6. After 6 weeks of diet, rats were killed and luminal contents from caecum and colon were removed and analysed for SCFA. Aliquots of the caecal samples were immediately processed for microbial counts. Wet and dry weights and $\mathrm{pH}$ values of intestinal contents were also determined.

\section{Short-chain fatty acid analysis}

For analysis of SCFA, faecal samples were homogenized in distilled water $(1: 5, \mathrm{w} / \mathrm{v})$ and centrifuged at $20000 \mathrm{~g}$ and $4^{\circ} \mathrm{C}$ for $5 \mathrm{~min}$. Then, $50 \mu \mathrm{l}$ internal standard $(10 \mathrm{~mm}-$ i-butyric acid), $280 \mu \mathrm{HClO}_{4}(0.36 \mathrm{M})$ and $270 \mu \mathrm{l} \mathrm{NaOH}$ (1 M) were added to $100 \mu \mathrm{l}$ supernatant fraction. Samples were mixed, frozen in liquid $\mathrm{N}_{2}$ and lyophilized. Lyophilizates were acidified with $200 \mu \mathrm{l}$ formic acid $(5 \mathrm{M})$ and sample volume was adjusted to $1 \mathrm{ml}$ by adding $800 \mu \mathrm{l}$ distilled water. Subsequently, mixed samples were transferred into vials and analysed by GC. SCFA were determined in two parallel preparations on an HP 5890 Series II Plus GC (Hewlett-Packard, Waldbronn, Germany) equipped with an HP Autosampler, HP GC Autosampler Controller and an HP Injector 7673. Separation of SCFA was done on an HP-free fatty acid phase capillary column (crosslinked free fatty acid phase; $30 \mathrm{~m} \times 0.53 \mathrm{~mm} \times 0.1 \mu \mathrm{m}$; split $1: 1$; flame-ionization detection; injection volume $1 \mu \mathrm{l})$. He gas was used as the carrier. The initial oven temperature of $85^{\circ} \mathrm{C}$ was kept constant for $0.5 \mathrm{~min}$, increased to $135^{\circ} \mathrm{C}$ at a rate of $7^{\circ} \mathrm{C} / \mathrm{min}$ and in $0.1 \mathrm{~min}$ to $160^{\circ} \mathrm{C}$ at a rate of $70^{\circ} \mathrm{C} / \mathrm{min}$, kept for $4 \mathrm{~min}$ at $160^{\circ} \mathrm{C}$ and decreased to the initial temperature of $85^{\circ} \mathrm{C}$ in $1 \mathrm{~min}$ at a rate of $70^{\circ} \mathrm{C} / \mathrm{min}$. The temperature of the injector was set at $200^{\circ} \mathrm{C}$ and that of the detector at $260^{\circ} \mathrm{C}$. SCFA concentrations are expressed in units of $\mu \mathrm{mol} \mathrm{SCFA} / \mathrm{g}$ dry weight of intestinal content. Total mol yield in SCFA ( $\mu \mathrm{mol})$ was calculated by multiplying SCFA concentration ( $\mu \mathrm{mol} / \mathrm{g}$ dry weight) with total weight ( $g$ dry weight) of caecal content.

\section{Microbial studies}

Approximately $0.2 \mathrm{~g}$ fresh collected faeces was immediately placed into pre-weighed tubes and diluted with prereduced buffered peptone water. In duplicates, $0.05 \mathrm{ml}$ of each dilution was plated on non-selective and selective media. Columbia blood agar (BioMérieux, Nurtingen, Germany), Endo agar (BioMérieux) and Rogosa agar (Fluka, Taufkirchen, Germany) were incubated aerobically at $37^{\circ} \mathrm{C}$ for the determination of total aerobes (for $48 \mathrm{~h}$ ), coliformic bacteria (for $24 \mathrm{~h}$ ) and aerobic lactobacilli (for $48 \mathrm{~h}$ ), respectively. Numbers of total anaerobes, Bacteroidaceae and Bifidobacterium sp. were determined after a $48 \mathrm{~h}$ anaerobic incubation of Columbia blood agar, Columbia blood agar supplemented with neomycin $(0.1 \mathrm{~g} / \mathrm{l}$; Fluka) and sodium deoxycholate $(0.2 \mathrm{~g} / \mathrm{l}$; Fluka) and Haenel-Müller-Beuthow media (composition (g/l): peptone, 10 ; yeast extract, $7 ; \mathrm{NaCl}, 3 ; \mathrm{Na}_{2} \mathrm{HPO}_{4}, 2 ;$ agar, 10 ; cystine, 0.5 ; cysteine, $0.5 ; \mathrm{NaN}_{3}, 0.1$; bromkresol green, 0.0125 ; neutral red, 0.00025; saline B, $2.5 \mathrm{ml}$ ). Saline B consisted of $(\mathrm{g} / \mathrm{l}): \mathrm{MgSO}_{4} .7 \mathrm{H}_{2} \mathrm{O}, 40 ; \mathrm{FeSO}_{4} .7 \mathrm{H}_{2} \mathrm{O}, 2$; $\mathrm{NaCl}, 2 ; \mathrm{MnSO}_{4} \cdot 2 \mathrm{H}_{2} \mathrm{O}, 2 \cdot 35$. The faecal microbial counts are expressed as $\log _{10}$ colony-forming units/g dry weight.

In addition, total bacteria and selected groups of plantcell-wall-degrading organisms were counted in caecal samples by fluorescent in situ hybridization (FISH) using the following 16S rRNA targeted oligonucleotide probes $\left(5^{\prime}\right.$ labelled with the indocarbocyanine dye; Interactiva, Ulm, Germany): (1) an equimolar mixture of five bacteria-directed probes (Eub 338, Eub 785, Eub 927, Eub 1055, Eub 1088) (Giovannoni et al. 1988; Amann et al. 1990; Lee et al. 1993), referred to as Eub mix (Kleessen et al. 2001), to detect all bacteria; (2) Bac 303 to detect Bacteroides (Manz et al. 1996) and Erec 482 to detect the Eubacterium rectale cluster (Franks et al. 1998). Approximately $0.3 \mathrm{~g}$ fresh caecal content was suspended in $500 \mu \mathrm{l}$ sterile PBS at $\mathrm{pH} 7.4(130 \mathrm{~mm}-\mathrm{NaCl}, 10 \mathrm{~mm}-$ $\mathrm{Na}_{2} \mathrm{HPO}_{4}-\mathrm{NaH}_{2} \mathrm{PO}_{4}$ ) and fixated for at least $4 \mathrm{~h}$ by adding three vol. of fresh paraformaldehyde $(40 \mathrm{~g} / \mathrm{l})-\mathrm{PBS}$ $(\mathrm{pH} 7.2)$ at $4^{\circ} \mathrm{C}$ according to Amann et al. (1990). Samples were washed in PBS once, re-suspended in a 1:1 mixture of PBS and $96 \%(\mathrm{v} / \mathrm{v})$ ice-cold ethanol and stored at $-20^{\circ} \mathrm{C}$ until FISH analysis. FISH was done by a modified method of Schwiertz et al. (2000). Before hybridization fixed samples were briefly vortexed and immediately centrifuged at $9 \mathrm{~g}$ and $4^{\circ} \mathrm{C}$ for $3 \mathrm{~min}$. Then, $10 \mu \mathrm{l}$ of each supernatant fraction was applied to a single well on a 3-aminopropyltriethoxysilane- (Sigma, Taufkirchen, Germany) coated slide (Maddox \& Jenkins, 1987). Air-dried samples were dehydrated in 60, 80 and $96 \%$ (v/v) ethanol ( 3 min each), dried and treated with $10 \mu \mathrm{l}$ lysozyme buffer $(100 \mathrm{mM}-$ tris(hydroxymethyl)-aminomethane- $\mathrm{HCl}(\mathrm{pH} 8.0), 50 \mathrm{~mm}$ EDTA, $1 \mathrm{mg}$ lysozyme (130000 U/mg; Boehringer, 
Mannheim, Germany)) on ice for $8 \mathrm{~min}$ to improve the permeability of cell envelopes. After washing slides in water and dehydration in the ethanol series as described earlier, hybridizations were performed for $16 \mathrm{~h}$ at $46^{\circ} \mathrm{C}$ $\left(50^{\circ} \mathrm{C}\right)$ in humid chambers after addition of a mixture of $1 \mu \mathrm{l}$ probe $(50 \mathrm{pmol} / \mu \mathrm{l})$ and $10 \mu \mathrm{l}$ hybridization buffer $(0 \cdot 9 \mathrm{M}-\mathrm{NaCl}, 0.1 \mathrm{~g} \mathrm{SDS} / 1$ and $10 \mathrm{~mm}$-tris(hydroxymethyl)aminomethane- $\mathrm{HCl}, \mathrm{pH} 7.4)$. Slides were washed in hybridization buffer for $20 \mathrm{~min}$ at $48^{\circ} \mathrm{C}\left(52^{\circ} \mathrm{C}\right)$, subsequently treated with SlowFade ${ }^{\circledR}$ Antifade Kit (Molecular Probes, Leiden, The Netherlands) and then examined using a Carl Zeiss Axioplan epifluorescence microscope (Carl Zeiss, Jena, Germany) equipped with a $100 \times 1.30$ Plan Neofluar Ph3 oil immersion objective, HBO 100 W/3 Hg lamp, the filter block 15 and a 12-bit cooled CCD camera (SensiCam ${ }^{\circledR} 370$ KL; PCO Computer optics, Kehlheim, Germany). Images were taken and fluorescent cells were counted by KS300 software (Carl Zeiss). Microbiota in caecal contents are expressed as $\log _{10}$ total organisms and were calculated by multiplying caecal microbiota concentration ( $\log _{10}$ organisms/g dry weight) with total weight ( $g$ dry weight) of caecal content.

\section{Statistical analysis}

Results are expressed as mean values and standard deviations. Before statistical analysis, microbial cell counts were transformed to $\log _{10}$ numbers in order to improve homogeneity of variance. Data concerning SCFA, faecal $\mathrm{pH}$ values, dry and wet weights of intestinal contents as well as microbial counts, respectively, were analysed by an unpaired Student's $t$ test to determine significant differences between control and experimental groups. $P$ values of $<0.05$ were considered significant.

\section{Results}

\section{Food intake and body-weight gain}

Throughout the entire experimental period, rats were in good health. No significant differences in food intake between the control group (22.3 (SD 1.6) $\mathrm{g} / \mathrm{d}$ ) and the rats fed the juice colloid diets $(20.3$ (SD 4.6) $\mathrm{g} / \mathrm{d}$ for both colloids) were observed. Rats fed with the AIS diet consumed 24.0 (SD 2.8) $\mathrm{g}$ food/d. At the end of the experimental feeding period, the mean body weight of all rats had risen to 180 (SD 19) g. Weight gain in the control group was highest (207 (SD 31) g) and lowest in the rat group fed with juice colloids 4B (156 (SD 19) g; $P<0 \cdot 05$ ). Supplementation of diets with juice colloids $1 \mathrm{~B}$ or AIS led to a gain in body mass of 170 (SD 26) and 189 (SD 17) $\mathrm{g}$ within 6 weeks, respectively. The weight of the rats of the former diet group differed significantly from that of the control group $(P<0 \cdot 05)$.

\section{Total intestinal contents and $\mathrm{pH}$ values}

Intake of apple DF resulted in an increase in wet and dry weight of caecal contents $(P<0 \cdot 05$; Table 2$)$. These results were also detected for distal colon contents in rats supplemented with juice colloids 4B. However, no significant differences in weight were found for proximal colon contents (data not shown). Furthermore, DF from apples lowered luminal $\mathrm{pH}$ values in caecum and colon $(P<0.05)$, which was most prominent if the AIS-containing diet was given.

\section{Short-chain fatty acids}

Consumption of apple DF positively affected the total yield in SCFA in intestinal segments examined as indicated by a rise in total SCFA concentration (Table 3). Especially in the caecum, the main site of bacterial fermentation in rats, significant differences were detectable between control rats and rats fed with either juice colloids or AIS $(P<0 \cdot 05)$. Due to rapid absorption of SCFA by the colonic epithelium, luminal SCFA concentrations continuously decreased throughout the gut passage (caecum to distal colon) and reached their minimum in faeces. Rats fed with apple DF excreted faeces containing higher total SCFA concentrations than control $(P<0.05)$. In all rat groups, acetate was the dominant SCFA. Furthermore, its concentration was higher in caecal contents if apple DF

Table 2. Effect of colloids isolated from apple pomace extraction juices produced by enzymic liquefaction and of alcohol-insoluble substance (AIS) from apples on $\mathrm{pH}$ values, total wet and dry weight $(\mathrm{g})$ of intestinal contents in rats $†$

(Mean values and standard deviations for ten rats per group)

\begin{tabular}{|c|c|c|c|c|c|c|c|c|}
\hline & \multicolumn{2}{|c|}{ Control } & \multicolumn{2}{|c|}{ Colloids 1B } & \multicolumn{2}{|c|}{ Colloids 4B } & \multicolumn{2}{|c|}{ AIS } \\
\hline & Mean & SD & Mean & SD & Mean & SD & Mean & SD \\
\hline \multicolumn{9}{|l|}{$\mathrm{pH}$ value } \\
\hline Caecum & $7 \cdot 2$ & 0.1 & $6 \cdot 9^{*}$ & 0.2 & $7 \cdot 0^{*}$ & 0.2 & $6 \cdot 6^{\star}$ & 0.2 \\
\hline $\begin{array}{c}\text { Colon } \ddagger \\
\text { Wet weight }\end{array}$ & $6 \cdot 8$ & 0.1 & $6 \cdot 6^{*}$ & 0.1 & $6 \cdot 6^{\star}$ & 0.1 & $6 \cdot 3^{*}$ & 0.1 \\
\hline Caecum & $2 \cdot 81$ & 0.40 & $3.76^{\star}$ & 0.46 & $3 \cdot 60^{*}$ & 0.51 & $6 \cdot 51^{*}$ & 0.99 \\
\hline Colon‡ & 0.75 & 0.40 & 0.94 & 0.35 & $1 \cdot 15^{\star}$ & 0.26 & 0.81 & 0.44 \\
\hline \multicolumn{9}{|l|}{ Dry weight } \\
\hline Caecum & 0.72 & 0.11 & $0.91^{*}$ & 0.10 & $0.88^{*}$ & 0.14 & $1.40^{*}$ & 0.34 \\
\hline Colon‡ & 0.41 & 0.16 & 0.45 & 0.10 & $0.59^{*}$ & 0.12 & 0.35 & 0.17 \\
\hline
\end{tabular}

* Mean value was significantly different from that for the control group $(P<0.05)$.

†For details of diets and procedures, see Table 1 and p. 608.

‡Distal colon. 
Table 3. Effect of colloids isolated from apple pomace extraction juices produced by enzymic liquefaction and of alcohol-insoluble substance (AIS) from apples on caecal, colonic and faecal concentrations ( $\mu \mathrm{mol} / \mathrm{g}$ dry weight) of short-chain fatty acids (SCFA) in rats $\dagger$ (Mean values and standard deviations for ten rats per group)

\begin{tabular}{|c|c|c|c|c|c|c|c|c|}
\hline & \multicolumn{8}{|c|}{ Diets } \\
\hline & \multicolumn{2}{|c|}{ Control } & \multicolumn{2}{|c|}{ Colloids 1B } & \multicolumn{2}{|c|}{ Colloids 4B } & \multicolumn{2}{|c|}{ AIS } \\
\hline & Mean & SD & Mean & SD & Mean & SD & Mean & SD \\
\hline \multicolumn{9}{|l|}{ Total SCFA } \\
\hline Caecum & $196 \cdot 3$ & $34 \cdot 8$ & $325 \cdot 9^{*}$ & $41 \cdot 1$ & $396 \cdot 0^{*}$ & 95.4 & $265 \cdot 0^{\star}$ & $63 \cdot 4$ \\
\hline Proximal colon & $74 \cdot 0$ & $24 \cdot 4$ & $127 \cdot 4$ & $53 \cdot 1$ & $157 \cdot 1^{*}$ & $96 \cdot 1$ & 80.5 & $50 \cdot 0$ \\
\hline Distal colon & $45 \cdot 5$ & $18 \cdot 4$ & $91 \cdot 4^{\star}$ & $33 \cdot 0$ & $59 \cdot 2$ & $17 \cdot 1$ & $34 \cdot 4$ & $9 \cdot 6$ \\
\hline Faeces & $30 \cdot 8$ & $10 \cdot 3$ & $46 \cdot 1^{*}$ & $15 \cdot 3$ & $49 \cdot 9^{*}$ & $16 \cdot 7$ & $46 \cdot 8^{*}$ & $14 \cdot 5$ \\
\hline \multicolumn{9}{|l|}{ Acetate } \\
\hline Caecum & $140 \cdot 5$ & $25 \cdot 1$ & $243 \cdot 6^{\star}$ & $21 \cdot 4$ & $291 \cdot 4^{\star}$ & $63 \cdot 1$ & $189 \cdot 5^{\star}$ & $43 \cdot 4$ \\
\hline Proximal colon & $50 \cdot 5$ & $18 \cdot 2$ & $98 \cdot 4$ & $41 \cdot 1$ & $111 \cdot 6^{*}$ & $71 \cdot 6$ & 58.9 & $39 \cdot 5$ \\
\hline Distal colon & 31.9 & 11.4 & $64 \cdot 7^{*}$ & $20 \cdot 8$ & $45 \cdot 9^{\star}$ & $11 \cdot 3$ & $24 \cdot 0$ & $6 \cdot 3$ \\
\hline Faeces & $26 \cdot 6$ & 8.6 & $41 \cdot 2$ & $12 \cdot 3$ & $44 \cdot 2$ & $12 \cdot 6$ & $35 \cdot 8$ & $8 \cdot 2$ \\
\hline \multicolumn{9}{|l|}{ Propionate } \\
\hline Caecum & $39 \cdot 0$ & $6 \cdot 0$ & $67 \cdot 6^{\star}$ & $14 \cdot 8$ & $88 \cdot 5^{\star}$ & $28 \cdot 2$ & $47 \cdot 1$ & $11 \cdot 8$ \\
\hline Proximal colon & $15 \cdot 6$ & $4 \cdot 2$ & $23 \cdot 7$ & $9 \cdot 8$ & $37 \cdot 9^{*}$ & $20 \cdot 5$ & $14 \cdot 0$ & $6 \cdot 2$ \\
\hline Distal colon & $7 \cdot 6$ & $3 \cdot 8$ & $19 \cdot 6^{*}$ & $9 \cdot 9$ & $9 \cdot 0$ & $4 \cdot 3$ & $6 \cdot 1$ & $2 \cdot 0$ \\
\hline Faeces & $2 \cdot 2$ & $1 \cdot 0$ & 2.9 & 1.9 & $3 \cdot 8$ & $3 \cdot 0$ & $6 \cdot 0$ & $2 \cdot 4$ \\
\hline \multicolumn{9}{|l|}{ Butyrate } \\
\hline Caecum & $16 \cdot 8$ & $3 \cdot 7$ & $14 \cdot 7$ & 4.9 & $16 \cdot 1$ & $4 \cdot 1$ & $28 \cdot 4^{*}$ & $8 \cdot 3$ \\
\hline Proximal colon & 7.9 & $2 \cdot 0$ & $5 \cdot 3$ & $2 \cdot 2$ & $7 \cdot 6$ & 3.9 & $7 \cdot 6$ & $4 \cdot 3$ \\
\hline Distal colon & $6 \cdot 0$ & $3 \cdot 1$ & $7 \cdot 1$ & $2 \cdot 4$ & $4 \cdot 3$ & $1 \cdot 6$ & $4 \cdot 3$ & 1.4 \\
\hline Faeces & $2 \cdot 0$ & 0.7 & $2 \cdot 0$ & $1 \cdot 1$ & 1.9 & $1 \cdot 2$ & $5 \cdot 0$ & $3 \cdot 9$ \\
\hline
\end{tabular}

* Mean value was significantly different from that for the control group $(P<0.05)$.

$\dagger$ For details of diets and procedures, see Table 1 and p. 608 .

$\ddagger$ Total SCFA represents the sum of acetate, propionate and butyrate.

were present in the diet $(P<0 \cdot 05)$. Even the molar proportion of acetate was increased in the caecum of juice colloid-fed rats (data not shown). The caecal fermentation of juice colloids by gut bacteria resulted in distinctly higher concentrations of propionate as compared with the control group $(P<0.05)$. In addition, when calculating total mol yields of SCFA $(\mu \mathrm{mol})$ for caecal contents, even more than twice as many mol of acetate and propionate could be found in all apple DF-fed rats as compared with the control group $(P<0.05$; Fig. 1). However, only rats fed with the AIS diet had raised caecal butyrate levels also, due to microbial breakdown of the almost intact apple cell-wall material $(P<0 \cdot 05$; Table 3 and Fig. 1).

\section{Microbial studies}

In caecal contents, counts of total and some plant-cell-walldegrading bacteria were done by FISH. When feeding AIS numbers of total bacteria were higher as compared with control (Table 4). However, members of the E. rectale cluster $(P<0.05$ for AIS diet) as well as of the genus Bacteroides were increased in numbers if DF from apples were fed with the diets. In faeces, no significant differences were found in microbial plate counts with the single exception of the numbers of Bacteroidaceae, which nearly increased by $1 \log _{10}$ in rats fed with DF from apples (either juice colloids or AIS; $P<0.05)$. Faecal concentrations of total anaerobes showed a slight tendency to increase with apple DF whereas those of lactobacilli tended to decrease with colloids 4B or AIS. The slight increase in total aerobes and lactobacilli occurred with colloids $1 \mathrm{~B}$ in the diet.
However, bifidobacteria remained under the limit of detection in all investigated rat groups.

\section{Discussion}

A supplementation of diet with juice colloids from apple pomace extraction juices produced by enzymic liquefaction

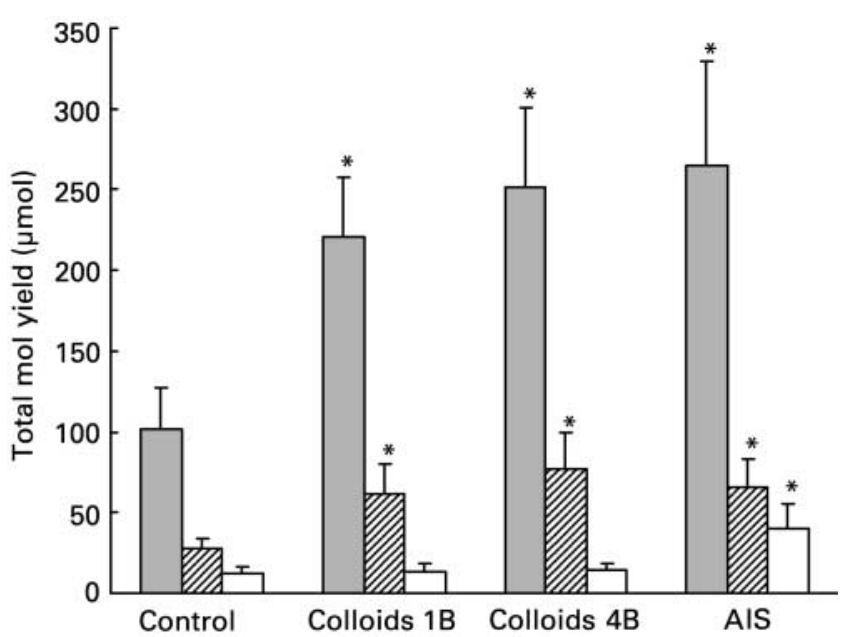

Fig. 1. Total mol yields of short-chain fatty acids ( $\mu \mathrm{mol})$ of caecal contents in rats fed control or $5 \%$ apple dietary fibre diet (1B or $4 \mathrm{~B}$ colloids from pomace extraction juices or alcohol-insoluble substance; AIS) for 6 weeks. Values are means for ten rats with standard deviations represented by vertical bars. *Mean values were significantly different from control $(P<0.05)$. ( $\square$ ), Acetate; $(\mathbb{C})$, propionate; $(\square)$, butyrate. For details of diets and procedures, see Table 1 and p. 608. 
Table 4. Effect of colloids isolated from apple pomace extraction juices produced by enzymic liquefaction and of alcohol-insoluble substance (AIS) from apples on microbiota in caecal contents ( $\log _{10}$ total organisms) and on faecal microbiota concentrations ( $\log _{10}$ colony-forming units/g dry weight) in rats $\dagger$

(Mean values and standard deviations for five or six rats per group)

\begin{tabular}{|c|c|c|c|c|c|c|c|c|}
\hline \multirow{2}{*}{ Diet... } & \multicolumn{2}{|c|}{ Control } & \multicolumn{2}{|c|}{ Colloids 1B } & \multicolumn{2}{|c|}{ Colloids 4B } & \multicolumn{2}{|c|}{ AIS } \\
\hline & Mean & SD & Mean & SD & Mean & SD & Mean & SD \\
\hline \multicolumn{9}{|l|}{ Caecal microbiota ( $n$ 5) } \\
\hline Total bacteria & $10 \cdot 94$ & 0.25 & $10 \cdot 88$ & 0.26 & $10 \cdot 84$ & 0.16 & $11 \cdot 21$ & 0.23 \\
\hline Eubacterium rectale cluster & 9.58 & 0.41 & 9.95 & 0.48 & 9.95 & 0.24 & $10 \cdot 47^{\star}$ & 0.59 \\
\hline Bacteroides & $10 \cdot 37$ & 0.32 & $10 \cdot 67$ & $0 \cdot 17$ & $10 \cdot 52$ & 0.20 & $10 \cdot 55$ & 0.18 \\
\hline \multicolumn{9}{|l|}{ Faecal microbiota $(n 6)$} \\
\hline Total aerobes & 7.78 & 0.71 & $8 \cdot 30$ & 0.50 & $7 \cdot 88$ & 0.59 & 7.83 & 0.26 \\
\hline Total anaerobes & $9 \cdot 27$ & 0.59 & $9 \cdot 60$ & $0 \cdot 13$ & 9.72 & 0.29 & 9.78 & 0.38 \\
\hline Coliforms & 6.55 & 1.12 & $6 \cdot 68$ & 0.31 & $6 \cdot 48$ & 0.41 & 6.85 & 0.33 \\
\hline Bacteroidaceae & $7 \cdot 83$ & 0.32 & $8 \cdot 68^{*}$ & 0.53 & $8 \cdot 65^{\star}$ & 0.35 & $8 \cdot 48^{\star}$ & 0.46 \\
\hline Bifidobacteria & $<3.30$ & - & $<3.30$ & - & $<3.30$ & - & $<3.30$ & - \\
\hline Lactobacilli & 8.02 & 0.81 & 8.40 & 0.47 & 7.28 & 0.93 & 7.55 & 0.36 \\
\hline
\end{tabular}

* Mean value was significantly different from that of control after 6 weeks of diet $(P<0.05)$.

†For details of diets and procedures, see Table 1 and p. 608.

did not significantly affect food intake, but lowered the body-weight gain in rats. A weight gain-lowering effect by dietary soluble NSP has been previously reported by Seal \& Mathers (2001) and Dongowski et al. (2002) although the food intake was unaffected by 5 or $10 \%$ guar gum or sodium alginate and $6.5 \%$ pectin, respectively. In contrast, feeding the AIS diet resulted in a $10 \%$ greater food consumption than control for covering energy requirements. The AIS diet contained the highest DF content according to the Association of Analytical Chemists method, mainly consisting of insoluble fibres (Table 1). When comparing soluble fibre, for example, B-juice colloids, with insoluble fibre, for example, AIS, a lower intake and body-weight gain was observed in juice colloid-fed rats. This finding is consistent with Frias \& Sgarbieri (1998), who fed guar gum or cellulose as soluble and insoluble fibre, respectively. Arjmandi et al. (1992) also reported that body-weight gains were significantly lower in pectin-fed rats than those fed cellulose.

DF derived from apples positively influenced the luminal concentrations of SCFA as demonstrated by their increased levels in intestinal contents. As a consequence, a decrease in $\mathrm{pH}$ values occurred. Similar results were reported by Berggren et al. (1993) for pectin. In the literature, a good fermentability is known for several DF sources from apples such as pectin (Englyst et al. 1987; Vince et al. 1990; Titgemeyer et al. 1991; Mortensen \& NordgaardAndersen, 1993; Barry et al. 1995), cell-wall components (Stevens et al. 1988; Guillon et al. 1995; Casterline et al. 1997) and pomace (Lebet et al. 1998). With apple DF diets, total amounts of acetate and propionate were two times higher than in control, which indicates the microbial fermentation of pectin (Englyst et al. 1987; Titgemeyer et al. 1991; Barry et al. 1995; Casterline et al. 1997) and arabinogalactan (Englyst et al. 1987) (Fig. 1). Also in other in vivo studies acetate was observed as the dominant SCFA released by intestinal fermentation of pectin (Berggren et al. 1993; Dongowski et al. 2002). Microbial degradation of the pectin monosaccharide unit galacturonic acid is correlated with the production of acetate
(Salvador et al. 1993). Bourquin et al. (1993) observed, in fermentation experiments with different cell-wall preparations from vegetables in vitro, that galacturonic acid was the most quickly fermented unit (up to $97 \%$ ) followed by arabinose (up to $96 \%$ ) and galactose (up to $90 \%$ ). From these results they concluded that the breakdown of cellwall components by gut bacteria proceeds in a certain hierarchy depending on the fermentability of each monosaccharide. Similar results were reported by Lebet et al. (1998) for apple pomace, as well as by Guillon et al. (1995) and Englyst et al. (1987) for apple cell-wall material and pectin from apples, respectively. In their in vitro experiments, degradation of galacturonic acid and arabinose was enhanced in residues of DF components from apples examined, whereas xylose was purely degraded. Our in vivo-tested juice colloids mainly consisted of oligo- and polymeric arabinans, rhamnogalacturonans and arabinogalacatans (Mehrländer et al. 2002) containing the monomers galacturonic acid, arabinose and galactose, which would also explain their good fermentability by gut microbiota in rats.

During passage through the intestinal tract, SCFA were absorbed by colonic mucosa as indicated by decreasing luminal SCFA concentrations (Table 3). In contrast to juice colloids, AIS resulted in an increase in butyrate level in caecal contents $(P<0.05)$, probably as a result of fermentation of a DF component only present in AIS. This component was obviously limited or only partially degradable because no further differences in butyrate concentrations were detected for the lower intestinal parts.

For a better comparison of the fermentation results the calculation of total mol yields is more favourable than that of concentrations. Therefore, the total mol yields of SCFA were calculated for the whole caecal contents, the caecum being the main location of fermentation activity. In rats fed with juice colloids, no differences in total mol yields in butyrate of caecal contents were found (Fig. 1). However, the AIS diet resulted in a four-fold rise in total mol of caecal butyrate as compared with control $(P<0.05)$. An increase in luminal butyrate levels is a 
prominent goal in nutritional colon cancer prevention (Jacobasch et al. 1999; Jacobasch \& Dongowski, 2000) due to its important role in homeostasis of colon epithelium (Roediger, 1980; Velázquez et al. 1996, 1997; Singh et al. 1997). Especially dietary fructo-oligosaccharides, oligofructose as well as resistant starch are known butyrogenic substrates for the intestinal microflora (Campbell et al. 1997; Schwiertz et al. 2002). Together with increasing butyrate in the caecum of AIS-fed rats the total numbers of the E. rectale cluster also increased by $1 \log _{10}$ unit. In rats fed juice-colloid diets, only a two-fold rise in this cluster was observed. Despite inducing higher intestinal butyrate levels resistant starch had no effect on members of the E. rectale cluster in vivo as reported by Schwiertz et al. (2002). With its almost intact cell-wall structure, AIS mainly consisted of insoluble DF components. Besides cell-wall polysaccharides such as xyloglucans, arabinans, arabinogalactans and rhamnogalacturonans AIS also contains cellulose in contrast to juice colloids. In primary cell walls, cellulose is partially fermentable by intestinal bacteria (Gray et al. 1993), if pectin is previously completely degraded (Guillon et al. 1995). The rise in the E. rectale cluster (cluster XIV according to Collins et al. 1994) and total mol of caecal butyrate could be explained by the partial fermentation of cellulose present in AIS. Some species of the E. rectale group are known cellulose-degrading organisms releasing acetate; for example, E. cellulosolvens, Clostridium lentocellum, and C. celerescens (Hippe et al. 1992). The latter organism also produces butyrate as a fermentation endproduct. Furthermore, there are some further butyrogenic species in this cluster that generate butyrate from acetate via the butyryl-coenzyme A-acetyl coenzyme A-transferase pathway (Barcenilla et al. 2000). Although the genus Bacteroides provides some members of cellulose degraders (Hill, 1995), no remarkable increase in cell numbers was detected for Bacteroides in caecal contents. However, it is not exactly known which of these species in the E. rectale cluster really belongs to the normal gut microflora in rats.

In faeces samples, bacterial cell numbers were determined by classic plate count procedures. When feeding either colloids from pomace extraction juices or AIS, members of the Bacteroidaceae were present in almost $1 \log _{10}$ higher counts than in faeces of control rats. Besides being cellulose degraders, they belong to the arabinogalactanand pectin-degrading organisms (Hill, 1995; Dongowski et al. 2000; Van Laere et al. 2000).

Another known arabinogalactan- and arabinan-degrading genus is bifidobacteria (Hill, 1995; Van Laere et al. 2000). Bifidobacteria have also been reported to be selectively growth stimulated by pectic oligosaccharides in vitro (Olano-Martin et al. 2002). In contrast to human intestinal microflora, bifidobacteria are only present in the large bowel of rats in low counts. In our experiments this genus remained under the detection limit in faeces and was therefore not determined in caecal contents of our Wistar strain. Noack et al. (1998) reported similar results for a $10 \%$ dietary pectin supplementation, whereas feeding $10 \%$ guar gum clearly stimulated bifidobacteria growth in rats. The present study provides data on the effects of juice colloids isolated from apple pomace extraction juices produced by enzymic liquefaction on intestinal fermentation products and microbiota in rats. Having the advantage of animal studies that allow access to intestinal samples of all gut segments, a clear rise in intestinal SCFA yield due to microbial fermentation of apple DF was found. Furthermore, results indicate a slight tendency to modulate gut microbiota by extraction juice colloids. However, our findings should also be verified by a study using human subjects in the future. In addition, plant-cell-wall-degrading members of the $E$. rectale cluster need to be identified in rat gut and their possible health-promoting properties examined.

From our point of view, juice colloids from pomace extraction juices tested in vivo are useful DF components from apples and may help to diminish the lack of daily recommended DF intake of at least $30 \mathrm{~g}$. Furthermore, pomace extraction juices providing such DF of fruit basis are a promising healthy and natural alternative to functional drinks.

\section{Acknowledgements}

The authors thank Monika Niehaus for excellent technical assistance, Dr Barbara Lorenz for microbial plate counts, and gratefully acknowledge Professor Dr Michael Blaut for providing laboratory facilities for FISH analysis. Work was supported by the FEI (Forschungskreis der Ernährungsindustrie e.V., Bonn), the AiF and the Ministry of Economics and Technology (project no. AiF-FV 11588B).

\section{References}

Amann RI, Binder BJ, Olson RJ, Chisholm SW, Devereux R \& Stahl DA (1990) Combination of 16S rRNA-targeted oligonucleotide probes with flow cytometry for analyzing mixed microbial populations. Appl Environ Microbiol 56, 1919-1925.

Arjmandi BH, Ahn J, Nathani S \& Reeves RD (1992) Dietary soluble fiber and cholesterol affect serum cholesterol concentration, hepatic portal venous short-chain fatty acid concentrations and fecal excretion in rats. $J$ Nutr $\mathbf{1 2 2}$, 246-253.

Barcenilla A, Pryde SE, Martin JC, et al. (2000) Phylogenetic relationships of butyrate-producing bacteria from the human gut. Appl Environ Microbiol 66, 1654-1661.

Barry JL, Hoebler C, Macfarlane GT, et al. (1995) Estimation of the fermentability of dietary fibre in vitro: a European interlaboratory study. Br J Nutr 74, 303-322.

Bauckhage K, Will F, Dietrich H, Sembries S \& Dongowski G (2000) Einsatz cellulasehaltiger enzympräparate zur behandlung von apfeltrester - Analysendaten und wertgebende inhaltsstoffe der gewonnenen produkte (Application of cellulase-containing enzyme preparations for the treatment of apple pomace. Analytical data and valuable ingredients of the corresponding products). Flüss Obst 67, 288-293.

Berggren AM, Björck IME \& Nyman EMGL (1993) Short-chain fatty acid content and $\mathrm{pH}$ in caecum of rats given various sources of carbohydrates. J Sci Food Agric 63, 397-406.

Bourquin LD, Titgemeyer EC \& Fahey GC (1993) Vegetable fiber fermentation by human fecal bacteria: cell wall polysaccharide disappearance and short-chain fatty acid production 
during in vitro fermentation and water-holding capacity of unfermented residues. $J$ Nutr 123, 860-869.

Campbell JM, Fahey GC Jr \& Wolf BW (1997) Selected indigestible oligosaccharides affect large bowel mass, cecal and fecal short-chain fatty acids, $\mathrm{pH}$ and microflora in rats. J Nutr 127, $130-136$

Casterline JL, Oles CJ \& Ku Y (1997) In vitro fermentation of various food fiber fractions. J Agric Food Chem 45, 2463-2467.

Collins MD, Lawson PA, Willems A, et al. (1994) The phylogeny of the genus Clostridium: Proposal of five new genera and eleven new species combinations. Int J Syst Bacteriol 44, 812-826.

Dongowski G, Lorenz A \& Anger H (2000) Degradation of pectins with different degrees of esterification by Bacteroides tetaiotaomicron isolated from human gut flora. Appl Environ Microbiol 66, 1321-1327.

Dongowski G, Lorenz A \& Proll J (2002) The degree of methylation influences the degradation of pectin in the intestinal tract of rats and in vitro. $J$ Nutr 132, 1935-1944.

Englyst HN, Hay S \& Macfarlane GT (1987) Polysaccharide breakdown by mixed populations of human faecal bacteria. FEMS Microbiol Ecol 95, 163-171.

Franks AH, Harmsen HJM, Raangs GC, Jansen GJ, Schut F \& Welling GW (1998) Variations of bacterial populations in human feces measured by fluorescent in situ hybridization with group-specific $16 \mathrm{~S}$ rRNA-targeted oligonucleotide probes. Appl Environ Microbiol 64, 3336-3345.

Frias AC \& Sgarbieri VC (1998) Guar gum effects on food intake, blood serum lipids and glucose levels of Wistar rats. Plant Foods Hum Nutr 53, 15-28.

Gibson GR (1999) Dietary modulation of the human gut microflora using the prebiotics oligofructose and inulin. J Nutr 129, 1438S-1441S.

Gibson GR, Beatty ER, Wang X \& Cummings JH (1995) Selective stimulation of bifidobacteria in the human colon by oligofructose and inulin. Gastroenterology 108, 975-982.

Gibson GR \& Roberfroid MB (1995) Dietary modulation of the human colonic microbiota: Introducing the concept of prebiotics. J Nutr 125, 1401-1412.

Giovannoni SJ, DeLong EF, Olsen GJ \& Pace NR (1988) Phylogenetic group-specific oligonucleotide probes for identification of single microbial cells. J Bacteriol 170, 720-726.

Gray DF, Eastwood MA \& Brydon WG (1993) Fermentation and subsequent disposition of ${ }^{14} \mathrm{C}$-labelled plant cell wall material in the rat. Br J Nutr 69, 189-197.

Guillon F, Renard CMGC, Hospers J, Thibault JF \& Barry JL (1995) Characterisation of residual fibres from fermentation of pea and apple fibres by human faecal bacteria. J Sci Food Agric 68, 521-529.

Hill MJ (1995) Bacterial fermentation of complex carbohydrate in the human colon. Eur J Cancer Prev 4, 353-358.

Hippe H, Andreesen JR \& Gottschalk G (1992) The genus Clostridium-nonmedical. In The Procaryotes, 2nd ed., pp. 1800-1866 [A Balow, HG Trueper, M Dworkin, W Harder and KH Schleifer, editors]. New York, NY: Springer Verlag.

Jacobasch G \& Dongowski G (2000) Ballaststoffe mit spezifischen Wirkungen (Dietary fibre with specific effects). In Praxishandbuch Functional Food, 2nd ed., pp. 1-34 [HF Erbersdobler and AH Meyer, editors]. Hamburg, Germany: Behr's Verlag.

Jacobasch G, Schmiedl D, Kruschewski M, Schmehl K (1999) Dietary resistant starch and chronic inflammatory bowl diseases. Int J Colorectal Dis 14, 201-211.

Kleessen B, Hartmann L \& Blaut M (2001) Oligofructose and longchain inulin: influence on the gut microbial ecology of rats associated with a human faecal flora. Br J Nutr 86, 291-300.
Kruse HP, Kleessen B \& Blaut M (1999) Effects of inulin on faecal bifidobacteria in human subjects. Br J Nutr 82, 375-382.

Lebet V, Arrigoni E \& Amadò R (1998) Measurement of fermentation products and substrate disappearance during incubation of dietary fibre sources with human faecal flora. LebensmWiss Technol 31, 473-479.

Lee S, Malone C \& Kemp PF (1993) Use of multiple 16S rRNAtargeted fluorescent probes to increase signal strength and measure cellular RNA from natural planktonic bacteria. Mar Ecol Prog Ser 101, 193-201.

Maddox PH \& Jenkins D (1987) 3-Aminopropyltriethoxysilane (APES): A new advance in section adhesion. $J$ Clin Pathol 40, 1256-1257.

Manz W, Amann R, Ludwig W, Vancanneyt M \& Schleifer KH (1996) Application of a suite of 16S rRNA-specific oligonucleotide probes designed to investigate bacteria of the phylum cytophaga-flavobacter-bacteroides in the natural environment. Microbiology 142, 1097-1106.

Mehrländer K, Will F, Dietrich H, Sembries S \& Dongowski G (2002) Structural characterization of oligosaccharides and polysaccharides from apple juices produced by enzymatic pomace liquefaction. J Agric Food Chem 50, 1230-1236.

Mortensen PB \& Clausen MR (1996) Short-chain fatty acids in the human colon: relation to gastrointestinal health and disease. Scand J Gastroenterol 31, Suppl. 216, 132-148.

Mortensen PB \& Nordgaard-Andersen I (1993) The dependence of the in vitro fermentation of dietary fibre to short-chain fatty acids on the contents of soluble non-starch polysaccharides. Scand J Gastroenterol 28, 418-422.

Noack J, Kleessen B, Proll J, Dongowski G \& Blaut M (1998) Dietary guar gum and pectin stimulate microbial polyamine synthesis in rats. $J$ Nutr 128, 1385-1391.

Olano-Martin E, Gibson GR \& Rastall RA (2002) Comparison of the in vitro bifidogenic properties of pectins and pectic-oligosaccharides. J Appl Microbiol 93, 505-511.

Prosky L, Asp NG, Schweizer TF, DeVries JW \& Furda I (1988) Determination of insoluble, soluble, and total dietary fiber in foods and food products: Interlaboratory study. J Assoc Off Anal Chem 71, 1017-1023.

Roediger WEW (1980) Role of anaerobic bacteria in the metabolic welfare of the colonic mucosa in man. Gut 21, 793-798.

Salminen S, Bouley C, Boutron-Ruault MC, et al. (1998) Functional food science and gastrointestinal physiology and function. Br J Nutr 80, S147-S171.

Salvador V, Cherbut C, Barry JL, Bertrand D, Bonnet C \& Delort-Laval J (1993) Sugar composition of dietary fibre and short-chain fatty acid production during in vitro fermentation by human bacteria. Br J Nutr 70, 189-197.

Schwiertz A, Le Blay G \& Blaut M (2000) Quantification of different Eubacterium spp. in human fecal samples with species-specific 16S rRNA-targeted oligonucleotide probes. Appl Environ Microbiol 66, 375-382.

Schwiertz A, Lehmann U, Jacobasch G \& Blaut M (2002) Influence of resistant starch on the SCFA production and cell counts of butyrate-producing Eubacterium ssp. in the human intestine. J Appl Microbiol 93, 157-162.

Seal CJ \& Mathers JC (2001) Comparative gastrointestinal and plasma cholesterol responses of rats fed on cholesterol-free diets supplemented with guar gum and sodium alginate. $\mathrm{Br} \mathrm{J}$ Nutr 85, 317-324.

Sembries S, Dongowski G, Bauckhage K, Will F \& Dietrich H (2000) Einsatz cellulasehaltiger Enzympräparate zur Behandlung von Apfeltrester - Ernährungsphysiologische Aspekte der Ballaststoffe (Application of cellulase-containing enzyme preparations for the treatment of apple pomace. Nutritional and physiological effects of the dietary fibre). Flüss Obst 67, 288-293. 
Singh B, Halestrap AP \& Paraskeva C (1997) Butyrate can act as a stimulator of growth or inducer of apoptosis in human colonic epithelial cell lines depending on the presence of alternative energy sources. Carcinogenesis 18, 1265-1270.

Steer T, Carpenter H, Tuohy K \& Gibson GR (2000) Perspectives on the role of the human gut microbiota and its modulation by pro- and prebiotics. Nutr Res Rev 13, 229-254.

Stevens BJH, Selvendran RR, Bayliss CE \& Turner R (1988) Degradation of cell wall material of apple and wheat bran by human faecal bacteria in vitro. J Sci Food Agric 44, $151-166$.

Titgemeyer EC, Bourquin LD, Fahey GC \& Garleb KA (1991) Fermentability of various fiber sources by human fecal bacteria in vitro. Am J Clin Nutr 53, 1418-1424.

Van Laere KMJ, Hartemink R, Bosveld M, Schols HA \& Voragen AGJ (2000) Fermentation of plant cell wall derived polysaccharides and their corresponding oligosaccharides by intestinal bacteria. J Agric Food Chem 48, 1644-1652.

Velázquez OC, Lederer HM \& Rombeau JL (1996) Butyrate and the colonocyte. Implications for neoplasia. Dig Dis Sci 41, $727-729$.

Velázquez OC, Lederer HM \& Rombeau JL (1997) Butyrate and the colonocyte. Production, absorption, metabolism, and therapeutic implications. Adv Exp Med Biol 427, 123-134.

Vince AJ, McNeil NI, Wager JD \& Wrong OM (1990) The effect of lactulose, pectin, arabinogalactan and cellulose on the production of organic acids and metabolism of ammonia by intestinal bacteria in a faecal incubation system. Br J Nutr 63, $17-26$.

Will F, Bauckhage K \& Dietrich H (2000) Apple pomace liquefaction with pectinases and cellulases: Analytical data of the corresponding juices. Eur Food Res Tech 211, 291-297. 